\title{
THE ISLAMIC LAW PERSPECTIVE OF UNIVERSITAS MUHAMMADIYAH SURAKARTA PENSION FUND MANAGEMENT
}

\author{
Ikhwanul Huda \\ Faculty of Islamic Studies, Universitas Muhammadiyah \\ Surakarta \\ email: ikhwanulhuda25@gmail.com
}

\begin{abstract}
Pension fund is one of the non-bank financial institutions that manages and implements program to generate retirement benefits. Pension fund is one of potential resources of fund which operation can be based on either conventional or Islamic principle. This research will focus on the type of contracts used by Universitas Muhammadiyah Surakarta (UMS) Pension Fund whether its operation conforms the requirements of shariah princple or not. This research aims to know, elaborate and evaluate the conformity of shariah principle in the UMS Pension Fund operation. The type of research carried out here is qualitative with the descriptive evaluative approach. The data is obtained through observation, documentation and interview. The result of the research shows that the contracts used in managing the fund by UMS Pension Fund are mudārabah, wakalah, ijārah and hibah. Mudārabah contract is used between the pension fund and the participants as well as between pension fund and investee. Wakalah contract is used between the employer which is UMS in this case and the pension fund. Meanwhile, hibah contract is used between employer and participants.
\end{abstract}

Keywords: Management, Pension Fund, Islamic Law. 


\section{INTRODUCTION}

Pension fund has many aspects embedded within it, they are social, psychology and economic aspect. An individual or employee will continously struggle to strengthen or sustain their economic welfare right along with their increasing age. This can be achieved through enrolling at many financial programs such as individual saving, life insurance or joining as member of Pension Fund run by private organization or by government. Welfare during retirement of society or employees in general related to the social and psychological stability because the certainty of peace of life in the retirement days will affect the behavior of society, both in the company and in the wider community. In addition, the development of pension fund institutions themselves is also one of the social outcomes and economic growth of the community, especially modern companies (Tunggal, 1996).

One of the pension fund institutions that manages funds as long-term savings collected specifically for the purpose of providing benefits to employees when they reach retirement age is the Pension Fund of Universitas Muhammadiyah Surakarta (we will call it as PFUMS hereafter) which is located at Siti Walidah Main Building, Muhammadiyah University, Surakarta. The Pension Fund was formed by the Universitas Muhammadiyah Surakarta with the decision of the Chancellor of that university.

Pension Fund of Universitas Muhammadiyah Surakarta provides guarantees to employees of the Muhammadiyah University of Surakarta after retirement so that they are more productive and loyal during their working age. In that state, they will not worry about their fate at retirement. However, it is important to see whether the management of the PFUMS is in accordance with sharia or not. In addition to that, it is also 
important to investigate whether PFUMS involves usury and conventional practive during its investment which is prohibited by Islam.

In the view of Islam, an activity that raise and attracts benefit. Nevertheless whether the benefit is in accordance with the principle of Islam or only gives benefit for some parties while harming another party. For the case of pension fund, there are two types of it, namely conventional pension fundsand Islamic pension fund. For the conventional pension fund, it involves usury and conventional financial instruments during its investment process. Of course such management is prohibited by Islamic religion. Meanwhile, the management of Islamic pension fund always try to avoid the interest and any conventional financial instruments.

Based on the background described above, the are several issues this research aims to investigate. First, this study is focusing on what type of contract is used by the management of PFUMS. This first aim is followed by the Islamic Law perspective on the management of PFUMS which constitutes as the second focus in this research. By carrying out field research with the descriptive qualitative approach, this paper will try to figure out the aforementioned issues concerned in this topic.

\section{LITERATURE REVIEW}

Pension Fund is not something that recently appears in modern day. It has been practiced far before 21 th century. Pension fund is one of the non-bank financial institutions in Indonesia that has activities to guarantee the welfare of the community both for pension and accident purposes. The exact definition of Pension Fund can be seen in Chapter I Article 1 in Law Number 11 of 
1992 on Pension Funds which states, "Pension Funds are legal entities that manage and run programs that promulgate retirement benefits."

In a more general definition, pension a decision made to prepare a number of funds or build financial planning so that the funds can be used to support a person during his retirement age. This means that when a retirement period comes, a person will still get financial income sourced from the pension fund. By having this fund, that person could do various activities that help him to get rid of his boredom since usually an employee was used to have full day activities in the office during his working period (Fahmi, 2014). Meanwhile, pension benefits mean periodic fund distribution paid to participants within time and through mechanism specified by article 1 number 1 and 9 at Pension Fund Law (Wahab, 2005).

In a more specific definition in the regard of Islamic Pension Fund, it has quiet different meaning. Mardani (2015) says that Islamic Pension Fund is defined as pension fund managed and run based on shariah principle. In other word, it must be free from forbidden elements in Islam such as interest, brabing, gharar (uncertainty), maisir (speculation) and void things.

The underlying Islamic principle for the practice of pension fund can be found at Chapter An-Nisa verse 9, "And let those [executors and guardians] fear [injustice] as if they [themselves] had left weak offspring behind and feared for them. So let them fear Allah and speak words of appropriate justice." In this verse we can see Allah encourages us not to left weak offspring. This can be done by many means, one of which is to participate in a pension fund. Allah also says in other verse, "O you who have 
believed, fear Allah. And let every soul look to what it has put forth for tomorrow - and fear Allah. Indeed, Allah is Acquainted with what you do." This verse also states that every people has to prepare better future. Meanwhile, it is also has been mentioned in the hadith, "Indeed, if you leave your offspring in a rich state, it is better for you than leaving them in a state of burden to others and begging for others."

There are several studies that has investigated pension fund of any institutions. For example, Meilani (2015) in her undergraduate thesis investigated the pension fund management of Bank Muamalat Indonesia. In that study, she explained the contractual form between the first party (i.e. the customer) with Bank Muamalat takes the mudarabah mutlaqah type of contract. Unfortunately, this makes the study conducted by her focuses too much on the mudaraba system from its definition until its implementation. The evaluation on the management of Bank Muamlaat pension fund is barely touched. Here, the main focus is not on the islamiw law perspective, but more towards mechanism of the mudāraba in Bank Muamalat pension fund.

Another study is done by Bukit (2012) for his undergraduate thesis as well. The context of the study was pension fund of Pertamina with the emphasis on the accountancy side. Thus, the research investigates the procedure and pension accountancy treatment at the Pertamina pension fund to see whether the accountancy standard is well applied or not. It is clearly seen from the study that she tried to seek the confomity between PSAK (accountancy standard) and the accounting application at Pertamina.

Hasibuan (2017) also have done similar research yet in a more general way. He made theoritical comparison between 
conventional pension fund management and the Islamic one. In the conventional practice for pension fund management, they invest in the instruments such as bonds including the Indonesia sovereign bond where the interest becomes one of its core source of profit. Meanwhile, the Islamic pension fund management uses the Islamic instruments such as sukuk, islamic mutual fund and Islamic stocks.

One other study was conducted by Rifanto (2017) who focuses more on the determinant of factors affecting customers intention in using pension fund instruments. In his study, the researcher analysed the impact of service, promotion and products towards the intention of customers in the context of Bank Muamalat Yogjakarta. The difference between this conducted research and the one that will be conducted here is that the initial contributes in the field of customer intention rather then Islamic legal aspect.

From the previous studies above, it is interesting to discuss the management of pension fund from Islamic law perspective apart from being it is not yet covered on the studies above.

\section{METHODOLOGY}

The approach taken in this study is descriptive-evaluative approach. Descriptive research is a systematic, factual and accurate description or illustration of phenomenon or relationships between phenomenons being investigated (Suprayogo and Tobroni, 2001). Meanwhile, the evaluative approach is every activity of collecting data or information that will be compared and drawing conclusion afterward. This conclusion is called evaluation (Arikunto, 1992). Evaluative research is basically focused on the final recommendation which confirms that an evaluation object can be maintained, repaired or even dismissed in line with the data obtained. 
This research was conducted to obtain data and produce conclusions on the practice of PFUMS with the regard on the evaluation of contracts used in the management. The type of data that will be observed will be both the primary and secondary data. The primary data is gathered through interview with the director of PFUMS. The author also observes each individual and the events that exist in the research location as well as making direct observation on the management of PFUMS regarding the used contract. The secondary data is obtained from the available literatures and documentations related to the topic of our interest. The data collection method used is the first observation, interview and documentation. Data analysis was carried out by means of the author searching for data by conducting review of books, literature, scientific papers and data that have relationship with the problem being studied.

For the research purpose, we limit the conformity of PFUMS practice towards fatwas issued by DSN-MUI. Neglecting this limitation causes bias in interpretation since there are enormous views regarding the muamalah practice. One mazhab might differ with another even though they embarked from similar evident (dalil) because the analysis tool (usul fiqh) is also different. Therefore, we stick on the fatwa issued by the highest authority in Indonesia for this field. The fatwas here are Fatwa DSN MUI Nomor No. 07/DSN-MUI/IV/2000, Fatwa DSN MUI Nomor No. 10/DSN-MUI/IV/2000 dan Fatwa DSN MUI NO. 88/DSN-MUI/ $\mathrm{XI} / 2012$ (Sam, et al., 2014).

\section{DISCUSSION AND RESULT}

\section{General Overview on the PFUMS}

UMS Pension Fund channeled the investment into three main categories. The categories are time deposit, sukuk and land purchase. The report of those three activities can be seen at the table below. 
Table 1. Time Deposit Investment by 2017

\begin{tabular}{|c|c|c|c|}
\hline No & Investment & $\begin{array}{l}\text { Value of investment } \\
\text { (in billion Rupiah) }\end{array}$ & $\begin{array}{l}\text { Percentage of } \\
\text { total time deposit } \\
\text { investment }\end{array}$ \\
\hline 1 & PT. Muamalat Indoensia, Tbk & $\mathrm{X}, 000$ & $4,20 \%$ \\
\hline 2 & PT. Bank Tabungan Negara, Tbk & $\mathrm{X}, 720$ & $9,43 \%$ \\
\hline 3 & PT. Bank Panin Syariah & $\mathrm{X}, 200$ & $11,50 \%$ \\
\hline 4 & PT. Bank Mega Syariah & $\mathrm{X}, 400$ & $8,99 \%$ \\
\hline 5 & PT. Bank Bukopin Syariah & $X X, 000$ & $14,04 \%$ \\
\hline 6 & PT. Bank CIMB Niaga Syariah & $\mathrm{X}, 100$ & $8,56 \%$ \\
\hline 7 & PT. Bank Victoria Syariah & $\mathrm{X}, 245$ & $7,36 \%$ \\
\hline 8 & PT. Bank Sinarmas Syariah & $\mathrm{X}, 028$ & $4,25 \%$ \\
\hline 9 & PT. Bank BRI Syariah & $\mathrm{X}, 000$ & $1,40 \%$ \\
\hline 10 & PT. Bank Jateng Syariah & $\mathrm{X}, 300$ & $3,23 \%$ \\
\hline 11 & PT. Bank BTPN Syariah & $\mathrm{X}, 250$ & $5,96 \%$ \\
\hline 12 & PT. Bank Mandiri & $\mathrm{X}, 500$ & $7,72 \%$ \\
\hline 13 & PT. Bank Syariah Mandiri & $\mathrm{X}, 000$ & $7,01 \%$ \\
\hline 14 & PT. BPRS Madina & $0, \mathrm{X} 00$ & $0,71 \%$ \\
\hline 15 & PT. BPRS Margirizki & $0, \mathrm{X} 000$ & $0,71 \%$ \\
\hline 16 & PT. BPRS Arta Surya Barokah & $\mathrm{X}, 000$ & $1,40 \%$ \\
\hline 17 & PT. BPRS Danagung & $0, \mathrm{X} 00$ & $0,71 \%$ \\
\hline 18 & PT. BPRS Dana Mulia & X.000 & $1,40 \%$ \\
\hline 19 & PT. BPRS Sragen & $0, \mathrm{X} 00$ & $0,71 \%$ \\
\hline 20 & PT. BPRS Al Mabrur & $0, \mathrm{X} 00$ & $0,71 \%$ \\
\hline \multicolumn{2}{|c|}{ TOTAL } & XX,293.55 & $100 \%$ \\
\hline
\end{tabular}

Note: This table shows time deposit investment done by PFUMS. The value of investment is showed in billion Rupiah form. The "X" sign in the value column is intentionally used instead of actual number to keep the privacy of PFUMS financial statement.

PFUMS channeled most of its fund into time deposit within various banks. It counts for $60 \%$ of whole investment (see table 4). In time deposit investment, The largest amount is channeled to PT. Bank Bukopin Syariah while the smallest amount is channeled to PT. BPRS Madina, PT. BPRS Margirizki, PT. BPRS Danagung, PT. BPRS Sragen. It is rational to keep small amount in BPRS 
rather than at regular bank since the initial cannot manage and accommodate big investment and typically meant for a narrower coverage compared to the regular bank.

Table 2. Sukuk Investment by 2017

\begin{tabular}{clcc}
\hline No & \multicolumn{1}{c}{ Investment } & $\begin{array}{c}\text { Value of investment } \\
\text { (in billion Rupiah) }\end{array}$ & $\begin{array}{c}\text { Percentage of } \\
\text { total sukuk } \\
\text { investment }\end{array}$ \\
\hline 1 & Bank Nagari & $\mathrm{X}, 000$ & $7,69 \%$ \\
2 & Ritel Seri SR-008 & $\mathrm{X}, 000$ & $11,54 \%$ \\
3 & SBSN PBS 012 & $\mathrm{XX}, 000$ & $42,31 \%$ \\
4 & Sukuk BRI Syariah & $\mathrm{X}, 000$ & $19,23 \%$ \\
5 & Sukuk Angkasa Pura 1 & $\mathrm{X}, 000$ & $11,54 \%$ \\
6 & Sukuk PT. Timah & $\mathrm{X}, 000$ & $7,69 \%$ \\
TOTAL & & $\mathbf{X X , 0 0 0}$ & $\mathbf{1 0 0 \%}$ \\
\hline
\end{tabular}

Note: This table shows sukuk investment done by PFUMS. The value of investment is showed in billion Rupiah form. The " $\mathrm{X}$ " sign in the value column is intentionally used instead of actual number to keep the privacy of PFUMS financial statement.

Meanwhile, sukuk investment done by PFUMS counts only for roughly one-third of total time deposit investment and fourth of whole investment (see table 4). The reason might include the difficulty on managing sukuk compared to time deposit to the extend that it needs human resource with deep understanding on financial market. In addition to that, sukuk issuance in Indonesia is still quite low compared to other region. At the table 2 above, it can be obviously seen that SBSN PBS 012 counts for almost half of total sukuk investment $(42,31 \%)$ while the smaller amount is channeled to both Bank Nagari and sukuk PT. Timah. 
Table 3. Land Purchase Investment by 2017

\begin{tabular}{clcc}
\hline No & Investment & $\begin{array}{c}\text { Value of investment } \\
\text { (in billion Rupiah) }\end{array}$ & $\begin{array}{c}\text { Percentage } \\
\text { of total land } \\
\text { purchase } \\
\text { investment }\end{array}$ \\
\hline 1 & SHM 215 & $\mathrm{X}, 625$ & $12,25 \%$ \\
2 & SHM 2764 & $\mathrm{X}, 625$ & $12,25 \%$ \\
3 & SHM 2716 & $\mathrm{X}, 625$ & $12,25 \%$ \\
4 & SHM 3666 & $\mathrm{X}, 625$ & $12,25 \%$ \\
5 & SHM 578 & $\mathrm{X}, 625$ & $12,25 \%$ \\
6 & SHM 412 & $\mathrm{X}, 080$ & $14,38 \%$ \\
7 & SHM 2893 & $\mathrm{X}, 625$ & $12,25 \%$ \\
8 & SHM 3665 & $\mathrm{X}, 593$ & $12,11 \%$ \\
\hline TOTAL & & $\mathbf{X X , 4 2 4}$ & $\mathbf{1 0 0 , 0 0 \%}$ \\
\hline
\end{tabular}

Note: This table shows land purchase investment done by PFUMS. The value of investment is showed in billion Rupiah form. The "X" sign in the value column is intentionally used instead of actual number to keep the privacy of PFUMS financial statement.

The last channel of investment is land purchase. In general, land purchase is considered as one of investment options on the basis that the price of land will always increase in the future. However, the fact that PFUMS only make investment of roughly one-sixth of whole investment indicates some possible reasons. The reason includes the availability of land which can be purchased by PFUMS. As it is obvious, it is difficult to find piece of wide land which is promising to get it sold at the far future.

Table 4. Total Investment by 2017 


\begin{tabular}{clcc}
\hline No & Investment & $\begin{array}{c}\text { Value of investment } \\
\text { (in billion Rupiah) }\end{array}$ & $\begin{array}{c}\text { Percentage of } \\
\text { total investment }\end{array}$ \\
\hline 1 & Time deposit & XX,293 & $60 \%$ \\
2 & Sukuk & XX,000 & $22 \%$ \\
3 & Land Purchase & XX,424 & $18 \%$ \\
TOTAL & & XXX,717 & $\mathbf{1 0 0 \%}$ \\
\hline
\end{tabular}

Note: This table shows total investment done by PFUMS. The value of investment is showed in billion Rupiah form. The " $\mathrm{X}$ " sign in the value column is intentionally used instead of actual number to keep the privacy of

PFUMS financial statement.

\section{The Contracts ('Aqd) Used in the Management of Pension Fund}

Every contract and transaction has its own pillar and condition in order to make it to be valid. For this research purpose, we will first elaborate shortly on the pillar and condition of the contracts used in the management of pension fund.

a. Wakalah

There are some important elements in wakalah which are the parties including the delegator and the delegate, as well as the subject matter being delegated. For the contracting parties, they must be in full capacity of their act, being lawful and and mature. The delegate also must be able to do the matters being delegated. Meanwhile, the subject matter itself must be clear and not in the contrary with shariah principle.

b. Mudarabah

The pillars and conditions for mudarabah are as following. Fund provider and fund manager must be lawful, mature and act on their free will. The offer and acceptance must be expressed to show their intention in forming the contract. 
The capital provided by fund owner can be in form of cash or asset but not in debt. The profit must be shared between parties as agreed in the contract while the financial loss is borne by the fund owner. The business activity as the exchange of the capital provided must be legal.

c. Ijarah

In ijarah, both parties must do the rental activity on their own concern. The parties involved also must understand fully the usage of subject matter to avoid dispute. The subject matter also must be ensured its usefullness from both shariah and economic perspective. The subject matter must also be able to get deliverd during contracting time. Since ijarah concern most on the benefit rather than on the tangible asset, thus the benefit must not be haram.

d. Hibah

Hibah requires the person must have the subject matter he wants to grant. The grant giver must have full capacity on his asset and wealth, mature, lawful and act on his willingness. Meanwhile, the grantee must really be in existence. Therefore, if the existence is still uncertain such as womb, the grant becomes void. In case the grantee exists during granting time but in the insane condition, the grant will be accepted and managed by its guardian (wali), or educator even though the person is stranger for that insane grantee (Sabiq, 1987).

While the above explanation is for the usual hibah, there is hibah that come under spesicif condition, called as hibah with condition (hibah bil sharth). Hibah is actually done without any expectation of reward, whether in the form of another hibah, gift, charity or any other means. However, hibah can be tied upon condition such as if a person says, "I will give 
you a motorcycle if you pray five times in mosque for 10 days." In this type of hibah, the giver of hibah might ask back the grant if the condition is not fulfilled. In one of hadith mentioned that a person gived something to Rasulullah by requesting some conditions that is Rasul must give some sort of things Rasul likes (Suhendi, 2002).

The Pension Fund is an alternative way to provide welfare guarantees to employees during the retirement period. The welfare guarantee is not only for employees who get retired, but also their families get that welfare. The main thing that has to be emphasized here is that the management of the Pension Fund must be in accordance with sharia principles and in accordance with the fatwa that has been established by the DSN-MUI (National Shariah Council).

The pension fund itself has been regulated by DSN-MUI on their fatwa to make it in line with the shariah requirements. The fatwas are Fatwa of DSN MUI Number No. 07 / DSN-MUI / IV / 2000, Fatwa of DSN MUI Number No. 10 / DSN-MUI / IV / 2000 and was joined by Fatwa DSN MUI NO. 88 / DSN-MUI / XI / 2012. It is discussed within the fatwa regarding the contract used by the Sharia Pension Fund in the Definite Retirement Benefit Plan (Program Pensiun Manfaat Pasti) and the Definite Retirement Fee Plan (Program Pensiun Iuran Pasti). Those fatwas above become reference for analyzing the validity and conformity between the contracts stipulated in the Sharia Pension Fund and the contract applied by the Pension Fund of the Muhammadiyah University of Surakarta (PFUMS).

PFUMS itself uses several contracts in their transaction. The details are as following: 
a. All the parties involved are the Head of University as the "Employer" while UMS employee as the "Participant". PFUMS here acts as the "Manager" of the pension fund, the real sector as the "Investee" and the retired UMS employee as the "Recipients" of pension benefits.

b. The contract used between Employer and Participant is hibah bi al-sharth (grants with condition) in the form of granting funds (mauhūb bih) from Employer (wāhib) to the Participant in organizing pension funds. The conditional grant happens when the requirements are met. The example is such as the right of Participant to receive pension fund benefit after that Participant being enrolled at the program for specific period and being retired at normal retirement age. The normal retirement age means 56 years old for the educative staff and 65 years for non-educative. Another condition is the accelerated age for minimum 10 years prior to normal retirement age. After the conditions are met, the Employer will provide pension benefits to Participants.

c. The contract used between Employer and Manager of Pension Fund is wakālah where the Employer delegates PFUMS to manage the wealth sourced from the premium and investment in accordance with the directions set by the founder. This type of practice can be nivestigated from the terms and rules of wakälah. First is the one who delegates. Shariah stipulates that the condition for this person is that he must be the legal owner who are allowed to act as he pleased over his ownership. In this case, the person who delegates is the Employer who acquire full ownership on the wealth. In addition to that, the person who makes delegation must be mukallaf (eligible to be responsible from Islamic point of 
view) and mumayyiz (able to distingusih between good and bad thing). Here it is obvious that the Employer is mukallaf and mumayyiz.

Second, the delegation (wakil) must be lawful and able to do the task assigned to him. In this case, the manager of PFUMS who accepts the delegation mandate is confirmed to be lawful and accepts the trust given by the Employers to the as the Manager.

Third, the matters being delegated must be known by the delegated party and doesn't go against shariah principle. In this case, PFUMS as the Manager understand well the mechanism, including the wealth of Pension Fund and regulations that have been passed. In addition to that, there is no element of riba and gharar within it. The Pension Fund also gives benefit for all parties.

d. The contract used between PFUMS and the Participant is mudāarabah. PFUMS acts as the fund manager (mud̄ārib) while particpant as the owner of the fund (sāhibul māl). PFUMS receives premium from the particpants which is equal to $5 \%$ of their monthly salary. PFUMS manages the premium obtained from participants by priortizing the interest of participants/retirees and those who are entitled to pension benefits. PFUMS has the right to deposit and invest the money under shariah system in order to grow it.

This practice can be investigated through the pillars and conditions of mudarabah. Some of the conditions states that both fund owner and manager must be lawful, the offer and acceptance between them also must express their intention in concluding contract. The offer and accpetance also must 
take into consideration some aspects, including the explicit expression on the purpose of the contract, being done within same time frame of contract as well as being written or through any other modern means of communication. The offer and acceptance which is expressed by PFUMS and the participant is written down in a paper.

Another pillar of mudarabah is the capital which is sum of money or any asset given by the owner to manager for business purpose. There are some conditions such us the amount of the capital must be known. In case the capital is in the form of asset, there need valuation in the time of contract. The capital cannot be in the form of debt since the capital must be paid to the manager directly, whether through instalment or paid in lump sum as stated in the contract between parties. In this regard, participants give the premium contribution by $5 \%$ of their monthly salary. This sum of money will be managed by PFUMS and given back to the participants during their retirement period.

The next pillar of mudarabah is about the profit which is the surplus of the initial capital. After the participants give the premium $5 \%$ of their monthly salary, PFUMS will manage and invest it until it grows in number. Afterwards, the profit must be splitted between both parties and cannot be given to only one party. The profit is distributed equally according to the agreed contract of mudarabah.

One other pillar is the type of business run by manager in exchange of the capital paid by fund owner. There are some conditions that need attention. The business activity is an exclusive right of the manager without any interruption from the fund owner. Howerver, fund owner has the right of supervision. 
Fund owner must not limit manager's activity that might hinder the goal of the mudarabah contract formation which is the profit. The manager also must not do things contrary to the shariah principle in their mudarabah activity. Therefore, the type of activity and business is an exclusive right of fund manager without any interruption from fund owner while still giving the owner right of supervision to ensure that the activities do not breach Islamic law and teachings.

e. The contract used between PFUMS and Investee is mudarabah and ijarah contract. In mudarabah contract, PFUMS invests the contribution of business founder and the participants' fund on Islamic financial institutions. The investment is in the form of deposit so that any sum of money accumulated by PFUMS can grow and given back to the respective owner later on. The profit earned will be disbursed through hibah or based on the profit sharing margin. This thing can be investigated from the pillars and conditions of mudarabah. The first pillar of mudarabah is that all parties must be lawful. In this regard, PFUMS acts as the fund owner while Investee as the fund manager. Second pillar is the offer and acceptance that must be pointed out by all parties to express their intention in concluding contract. In this regard, PFUMS and Investee will make written contract agreement by priortizing the benefit (maslahah) for both parties. The third is capital which is sum of money or asset given to the fund manager for business purpose. In this regard, PFUMS invests its money to Islamic financial institution for deposit where the profit will be calculated on the basis of profit loss sharing. Fourth condition is the profit which is surplus of initial capital. Afther the money invested by PFUMS grows, 
the profit obtained from the deposit must be distributed according to the agreement which is the profit loss sharing under mudaraba model. The next pillar of mudaraba is the business type as the exchange of given capital. Fund manager must obtain full and exclusive authority in managing the fund given by PFUMS as the fund owner. PFUMS must stop themselves in intervining in the management of the fund. However, PFUMS has right of supervision to ensure that the management avoids activitites prohibited by sharia.

For the ijarah contract, PFUMS invests up to $30 \%$ of its money in the corporate sukuk, particularly to the PT. Angkasa Pura, PT. Timah, Bank Nagari, PLN and some sovereign sukuks i.e. PBS12 and SR008. PFUMS as the sukuk holder who gives fund to the sukuk issuer so that the issuer can expand their business using the proceed of their sukuk. The issuer in the other hand must pay specific amount of money to the holder as the fee of ijarah while paying back the initial capital of sukuk at maturity time. PFUMS also uses mudaraba contract in investing their money through mudarabah sukuk i.e. to BRI Islamic. PFUMS as the sukuk holder gives fund to BRI Islamic as sukuk issuer for the purpose of funding specific project run by BRI Islamic. The profit will be distributed periodically according to the profit loss sharing agreement made by both parties.

f. In order to do the investment or non-investment activities, PFUMS is allowed to make agreement with other party under Islamic principle which also must be not contrary to the laws enacted by respective jurisdiction. In this regard, PFUMS makes investment in the form of deposit, sukuk and land 
purchase investment which is in line with shariah principle.

\section{Analysis from Islamic Perspective}

In general, the contract applied by the UMS pension fund conforms Sharia principles. Therefore the transactions applied are lawful since it fulfills the pillar and conditions of wakalah, mudarabah ijarah and hibah bil sharth (grants with condition). The contracts also don't contain elements which are prohibited by Islamic Sharia such as interest and gharar.

The contract used between Employer and Participants is the agreement of grant with condition which needs to be reviewed its pillars and conditions. The first condition is wahib or person who gives the grant. Wahib must have full ownership on the subject matter, must have full capacity to exercise his right, being mature and not under forced condition. In this case, wahib is the Employer. The next pillar is the grantee (mauhub lahu). The grantee must really exist during the time of grant. Here, the grantee is the Participant. The third pillar is the grant itself. The grant gave by Employer is the pension benefit in this case. It is important to be noted that the pension benefit is given to the Participant under certain conditions: (1) the Participant must be enrolled at the program for specific period of time, (2) the participant is retired at the regular retirment age or at the accelarated age. The fourth is the statement from Employer to the Recipient by both verbal and writing. Fifth is the distribution of pension benefit to the Recipient which is given monthly after declared as retiree from UMS and fulfilled the administration procedure of PFUMS. Judging from the analysis above, it can be seen that all pillars and conditions are fulfilled and thus conforms shariah requirements.

Meanwhile, the contract used between PFUMS and 
participant is mudarabah contract. The conditions are a. Management Mechanism of PFUMS

The main activity of the PFUMS is managing routine contributions from participants and founders to be invested in investments as it is set out in the investment direction made by the founders. Investment returns from funds is used to pay pension benefits to participants who have entered the retirement period.

PFUMS has set up the detail of the procedure and mechanism. Here, we would like to highlight some important points. The highlighted points will include aspects on membership requirements, premium payment, rights of participant, source of money, and investment process.

The membership of the pension fund begins when the employee is registered with the Pension fund as a participant and ends when the employee dies or retires or stops working by transferring his rights to another Pension Fund. This participant cannot resign or claim his rights from PFUMS if he still meets the membership requirements. Employees who are active as either educative or non-educative staff who reach the age of 18 , whether single or married, are eligible to be participant. For the premium payment, each of participant must pay fee equal to $5 \%$ of their monthly salary. The payment starts from the beginning participant enrolled and ends at the time the participant stops from the job by resigning, retiring or died.

As participant of PFUMS, all members are entitled for pension benefit which includes Normal Benefit, Accelerated Pension Benefit, benefit of retirement caused by disability and Late Pension Benefit. Normal benefit is given to participant who retired at normal age while the participant who retired in advance entitled the benefit of Accelerated Pension. In addition, participant 
who is forced to stop from their work due to disability will receive the benefit or retirement caused by disability. For the participant who get retired with the membership time range from 3 years up to the age below the accelerated pension age will be entitled for Late Pension Benefit. Apart from it, participants has right to raise their opinion and suggestion regarding portfolio progress to the Founder, manager and board of supervisor.

The initial wealth of the Pension Fund comes from the transfer of funds collected by the Muhammadiyah University of Surakarta as an Employer, which will then be collected from the Employer contribution, participant contribution (premium), investment returns, and transfer of pension funds.

1. Employer contribution

The employer in this case is the founder of the Pension Fund, the chancellor of the Muhammadiyah University of Surakarta, who is obliged to pay a fee which amount is determined based on the actuary calculation. The employer or founder must pay a contribution of $19 \%$ of the income or salary received for one month.

2. Participant contribution (premium)

Participant contributions are contributions intended to fund the pension program which is obliged for participants. This type of contribution has been regulated by the Pension Fund regulations of the Muhammadiyah University of Surakarta. Each participant must pay a contribution of $5 \%$ of his salary or income for one month. ${ }^{1}$

3. Investment return

Apart from Employer and participant contribution,

1 Interview with Muhroji, Director of Pension Fund Universitas Muhammadiyah Surakarta at 09/04/2018, 08.30 WIB. 
PFUMS source of fund comes from investment return.

The types of return obtained by PFUMS are below:

- $\quad$ Profit sharing

The return of protif sharing is income earned by PFUMS through investment instruments such as deposits, sukuk, and land price increment. ${ }^{2}$ Deposits are futures fund deposits whose withdrawals can only be made at a certain time based on the agreement of the depositing customer. Deposits themselves are one of the banking products used to make futures investments(Sam, et al., 2014). This type of investment is aimed at participants / individual customers or companies using mudarabah contract. Here, the calculation method obtained by the participant / customer will be done by means of profit sharing ratio.

The collected fund by PFUMS are invested using investment deposits into Islamic financial institutions. Some of Islamic Financial Institutions that become investment venues are PT. Muamalat Indonesia. Tbk, PT. State Savings. Tbk, PT. Bank Panin Syariah, PT. Bank Mega Syariah, PT. Bank Bukopin Syariah, PT. Bank CIMB Niaga Syariah, PT. Bank Viktoria Syariah, PT. Bank Sinarmas Syariah, PT. BRI Syariah Bank, PT. Bank Jateng Syariah, PT. BTPN Syariah Bank, PT. Bank Mandiri, PT. Bank Syariah Mandiri, PT. BPRS Madina, PT. BPRS Margirizki, PT. BPRS Arta Surya Barokah, PT. BPRS Danagung, PT. BPRS

2 Interview with Muhroji, Director of Pension Fund Universitas Muhammadiyah Surakarta at 09/04/2018, 08.30 WIB. 
Dana Mulia, PT. BPRS Sragen, PT. BPRS Al Mabrur. PFUMS plays the role as sohibul mal or fund owner while Islamic Financial Institutions as mudarib or the fund manager.

- Sukuk

Starting from 2016, PFUMS has been investing $30 \%$ of its fund in sukuk. Sukuk (Islamic bonds) is long-term securities based on shari'ah principles issued to sukuk holders which require issuers to pay income to sharia bond holders in the form of profit sharing / margins / fees as well as repayment of principal bonds at maturity (Sam, et al., 2014). There are two types of sukuk, sovereign sukuk and corporate sukuk. Sovereign sukuk is type of sukuk issued directly by the government. It is also possible for any city to issue municipal sukuk. In the other hand, corporate sukuk is the sukuk issued by institutions, agencies, corporation and sort of those entities. The purpose of the sovereign sukuk is to build country's infrastructure or finance other project. Some sukuk issued by the government that bought by PFUMS are PBS12 and SR008. In both PBS12 and SR008, government order the rental object (which is the property owned by government or any project) which later on managed and eventually offered to the public to become sukuk holder of the project. In this regard, PFUMS becomes the sukuk holder to fund the project held by government through sukuk PBS12. The proceed of sukuk issuance to rent government-owned 
property or fund any project. Later on, government gives payment benefit to the holders per six months for sukuk PBS12 and monthly for sukuk SR008 as the holders are entitled to rental benefit. This mechanism will apply until maturity.

Apart from the sovereign sukuk, PFUMS also buys the corporate sukuk from various companies. The companies are BRI Syariah, Angkasa Pura, PT. Timah, Bank Nagari and PLN. For BRI Syariah sukuk, the company issues mudarabah sukuk to increase the asset of the institution. PFUMS agrees to become sukuk holder through buying it at specific price. The proceed of the sukuk will be then used by BRI Syariah to open branches in several regions. The return on developing its business through sukuk proceed then distributed to the respective holders. In the other hand, Angkasa Pura, PT. Timah, Bank Nagari and PLN issues sukuk ijarah in which PFUMS invests its money. Those companies use the proceed to rent assets in order to develop their business. In exchange for the sum of money given, issuers must pay rental fees periodically to the sukuk holders. During the maturity date, the companies must pay back all the initial capital. The return distribution earned from renting activities between PFUMS (and also other sukuk holders) and Angkasa Pura, Bank Nagari as well as PT. TImah is paid per three months while investment return distribution for PLN is paid per two months. 
PFUMS gets monthly return from both deposit and sukuk. In addition to that, the land purchase as one other tool of investment by PFUMS provides great value increment. PFUMS bought piece of land last year since it saw the price increase of that particular land. ${ }^{3}$

The money pooled by PFUMS which consists of Employer and participant contribution is in fact fund that must be managed and invested in various instruments in order for the money to grow. This is simply because the long distance period between the time of the premium paid and the time participant gets pension benefit, starting from the participant get enrolled at PFUMS until his retirement. This is why the money pooled at PFUMS is said as having long-term characteristic. ${ }^{4}$

d. Transer of fund between of Pension Fund institutions The transfer between PFUMS and any other Pension Fund institutions occurs when the participant decides to make advanced retirement, exit from the pension plan or changing the Pension Fund institution. In that case, all the contributions paid to PFUMS will be returned to the respective participant or transferred to other institutions. By doing so, participant is still able to continue the pension contribution even though not attached any more to UMS. Of course, the continuation of contribution is given to other Pension Fund, not to the PFUMS.

3 Interview with Muhroji, Director of Pension Fund Universitas Muhammadiyah Surakarta at 09/04/2018, 08.30 WIB 4 Interview with Muhroji, Director of Pension Fund Universitas Muhammadiyah Surakarta at 09/04/2018, 08.30 WIB 
The wealth of Pension funds is separated from the wealth of the Work. The wealth of the Pension Fund is developed in accordance with the investment direction set by the founder. The wealth of pension funds cannot be used as collateral for loans of any kind, except in the form of investments that are allowed by laws and regulations in the field of pension funds. Letters, documents or any files regarding certain Pension Fund investments determined by the founder, are entrusted to the trustee.

\section{CONCLUSION AND SUGGESTION}

Based on the research above, we can make conclusion as following:

1. The contract used between Employer and Participant is hibah bi al-sharth (grants with condition) from Employer as wahib to the Employee as mauhub lah.

2. The contract used between Employer and Manager of PFUMS is wakālah (delegating authority) where the Employer delegates its authority to the Manager of PFUMS to manage the fee contribution as directed by the Establisher.

3. The contract used between PFUMS and Participant is muḍārabah where PFUMS act as muḍārib (manager) while Participant as șāhibul māl (fund owner).

4. The contract used between PFUMS and investee is mudārabah and ijārah where PFUMS invests all contributions collected into three main categories of channel: time deposit, sukuk and land purchase.

5. For the shariah conformity of PFUMS towards the available fatwa which includes Fatwa of DSN MUI 07/DSN-MUI/ 
IV/2000, Fatwa of DSN MUI 10/DSN-MUI/IV/2000 and Fatwa of DSN MUI NO. 88/DSN-MUI/XI/2013, we find that all contracts applied by PFUMS have fully followed the requirement. In addition to that, the management of fund doesn't involve any type of gharar and riba. Thus, we conclude that the transactions are shariah compliance.

Apart from the conclusion, it is also important to give suggestion based on the research result that has been summarized above. Even tough PFUMS succeed in implementing the contracts based on shariah requirements, there are still points to emphasize. One of the points is keeping the good work PFUMS has done so that it will always kept on the track of Islamic finance. Business always brings turbulence. Once it happens, PFUMS must still hold tightly the Islamic principle that they currently do.

\section{REFERENCES}

Arikunto, S., 1992. Prosedur penelitian: Suatu pendekatan praktik. Jakarta: Rineka Cipta.

Bukit, E. O., 2012. Analisis Penerapan Pernyataan Standar Akuntansi Keuangan 18 Mengenai Akuntansi Dana Pensiun Pertamina. Universitas Hasanudin Makasar: Bachelor Thesis.

Fahmi, I., 2014. Bank dan Lembaga Keuangan Lainnya Teori dan Aplikasi. Bandung: ALFABETA.

Hasibuan, R.I.P., 2017. Dana Pensiun Dalam Perspektif Hukum Bisnis Syariah. Al-'Adalah, 13(3), pp.99-108.

Mardani, 2015. Aspek Hukum Lembaga Keuangan Syariah di Indonesia. Jakarta: Prenadia Grup. 
Meilani, T., 2015. Sistem Pengelolaan Dana Pensiun Pada PT Bank Muamalat Indonesia, Tbk. Universitas Islam Negeri Syarif Hidayatullah Jakarta: Bachelor Thesis.

Rifanto, M., 2017. Faktor yang Mempengaruhi Minat Nasabah Menggunakan Produk Dana Pensiun (Studi Kasus pada Bank Muamalat Cabang Jogjakarta). Universitas Islam Negeri Sunan Kalijaga Yogyakarta: Bachelor Thesis.

Suprayogo, I., \& Tobroni, 2001. Metodologi Penelitian SosialAgama. Bandung: Remaja Rosdakarya.

Sabiq, S., 1987. Fikih Sunnah translated by Kamaludin A. Marzuki. Bandung: Al-Ma'arif.

Sam, M.I., et al., 2014. Himpunan Fatwa Keuangan Syariah: Dewan Syariah Nasionaal MUI. Jakarta: Erlangga.

Suhendi, H., 2002. Fiqh Muamalah. Jakarta: RajaGrafinda Persada

Tunggal, A.W., 1996. Dasar-dasar akuntansi dana pensiun. Jakarta: Rineka Cipta.

Wahab, Z., 2005. Segi Hukum Dana Pensiun. Jakarta: RajaGrafindo Persada. 